\author{
PHILIP TAYLOR
}

\title{
Minorities at Large: New Approaches to Minority Ethnicity in Vietnam
}

\section{$\mathrm{P}$} owerful yet conflicting images dominate the representation of ethnic minorities in Vietnam. The country is home to great cultural diversity; officially there are fifty-three national minorities, making up about 14 percent of the nation's population. This diversity is showcased in museums, documentaries, cultural festivals, and tourist attractions, indicating the positive value attached to the project of Vietnam as a multiethnic nation. Yet the ethnic minorities are also reported to be living in abject poverty, which is said to be due to their backward and unsustainable ways of life. For many years, the authorities have prosecuted far-reaching economic, social, and cultural reforms in minority areas, aiming to raise living standards and draw disparate peoples into the national community. Such reforms have been criticized by some observers as efforts at assimilation. Ethnonationalist movements, religious conversions, and political demonstrations exemplify the discontent that many groups feel with the direction of these policies. Officially, these manifestations of discontent are often taken not as legitimate local expressions but as signs that outsiders are, once more, fomenting disunity among Vietnam's peoples.

This great wealth of minority cultures is represented, contradictorily, as a national resource, a vanishing reality, a development obstacle, or a security problem. However, these representations also share two assumptions: that the traditional worlds of the ethnic minorities have changed irrevocably and

Journal of Vietnamese Studies, Vol. 3, Issue 3, pps. 3-43. ISSN 1559-372x, electronic ISSN 1559-3738. (C) 2008 by the Regents of the University of California. All rights reserved. Please direct all requests for permission to photocopy or reproduce article content through the University of California Press's Rights and Permissions website, http://www.ucpressjournals.com/reprintinfo.asp. DOI: $10.1525 /$ vs.2008.3.3.3 
that this change has profoundly affected the agency, social space, and voice of such peoples. This essay identifies these shared assumptions and puts them to the test, before exploring new research that embodies an alternative approach to minority ethnicity in Vietnam.

First among these assumptions is that ethnic minorities were traditionally self-regulating societies. Their cultural distinctiveness is a function of their historical, geographical, and social remove from the ethnic majority, from the markets and cities of the plains, and from global linkages. Today, however, this remove is no longer a reality; ethnic minorities are determined to an unprecedented degree by external factors that they can scarcely hope to influence. With their autonomy undermined by the incursions of armies, modernizing reforms, resource extraction, and a flood of new migrants, their traditional ways of life are no longer possible, or relevant. Notwithstanding the massive transformation of their worlds, the ethnic minorities still display some measure of agency, either by resisting state-directed changes or by asserting their irreducible distinctiveness as a people.

Second, it has been assumed that the minorities are inescapably part of the national project. The delineation of national borders, the census, and the ethnological survey have constituted "national minorities," who are assigned a name, place, and rank within the modern nation, written into national history, and reformed in line with national mores. Their subjection to lowland centers of power, now more intense than in the past, is continuous with an older, paternalistic orientation toward the diverse peoples living on the margins of the traditional Vietnamese polity. Faced by unprecedented pressures on their traditional way of life, including the effects of centrally directed globalization, many convert to world religions or search for allies across national borders. Such transnational affiliations are considered by some to be symptoms of a profound crisis, not only affecting the groups concerned but also threatening the integrity of the nation itself.

Finally, having once lived according to largely localized criteria and standards, the ethnic minorities today are overwhelmingly represented through external frames of reference. They are subject to a systematic official project of ethnic classification and counting. Their age-old ways of life are depicted in development reports funded by international agencies as "poor," "backward," and "deficient" in relation to the ethnic majority. Their traditional 
cultures exist largely only in staged performances that satisfy stereotypes about minorities held by lowlanders, the state, or tourists. When they espouse official development criteria, they display a regrettable inferiority complex. When they protest, their voice is deemed to be unrepresentative. Either way, they are seen as the mouthpieces of others.

In a word, the prevailing image of ethnic minorities in Vietnam is carceral: they are subjugated, disciplined, and circumscribed. As critics of state policy argue, their freedom has been lost; they are overrun, overwhelmed, and determined by forces over which they have little or no control. State officials argue, to the contrary, that government policies have freed the minorities from their traditional shackles of dependency, ignorance, and outmoded livelihoods and customs. Ethnic minorities are confined within the nation-state, pressed into conformity with mainstream cultural standards or marginalized, with no way out barring salvation in a transnational religious identity, radical opposition to the nation-state, or cross-border flight. Ethnic minorities in Vietnam, perhaps more than in most other countries, are subjects of disciplining power/knowledge. They are comprehensively objectified, classified, and spoken for by others.

This carceral hypothesis informs nearly all writings on minority ethnicity in Vietnam, yet it flourishes in the absence of sustained empirical work among ethnic minority populations. While state policies are often said to have had dramatic transformative effects on minority people's traditional ways of life, little ethnographic work has been done to explore the consequences of these policies. Few studies have examined the extent to which socalled national minority groups identify with the nation, or the importance of transnational linkages among the many groups whose populations span national borders. The attention devoted by foreign anthropologists to the rationales of state policy is matched only by the attention they devote to the discipline of anthropology. Surprisingly little attention has been devoted to ethnic minorities themselves. A mere handful of ethnographies exist that provide a nuanced account of their living conditions and concerns.

Of course, scholars face continuing problems of access to field sites, not to mention political constraints on reporting their results. Many foreign scholars subscribe to a reigning model in the social sciences that deems the peoples subject to ethnographic inquiry to be preconstructed by received 
imaginaries and disciplining constraints. As a result, investigations into living conditions and ethnic identities concentrate to a marked extent on state policy documents and official ethnographic projects. Surveying what stands for the ethnographic record of Vietnam of the postwar era, one comes away with a view of the minorities as governmentalized subjects of social engineering, applied anthropology, and official classification. And yet, with very little basic research into how people live and how they think, such a conclusion remains lodged firmly in the realms of speculation. The lens through which minority ethnicity in Vietnam is viewed greatly magnifies the power, the coherence, and the voice of the state. When the focus changes from the state and its agents to the ethnic minorities, it seems much harder to detect signs of agency. They are impotent, suffocated, and voiceless, save when lashing out in desperate and seemingly hopeless protests. Subnational or transnational identifications are relevant only insofar as they represent a provocation to the nation-state's containment project. The state's view and those of ethnologists matter greatly, shaping the social terrain and the categories through which ethnic minorities can be known.

This essay challenges this prevailing approach to minority ethnicity in Vietnam by drawing out the implications of recent research. This is new research whose scholarly importance lies in its return to traditional ethnographic and socially grounded approaches to this subject.

Based on these research findings, this essay suggests the need to scale back claims made about the rupture that ethnic minorities are experiencing, as well as about the extent of the state's transformative efficacy. Shedding light on the contemporary conditions in which traditions are maintained and deployed and in which distinctions are reproduced, it questions the unidirectionality of change and challenges the idea that the locus of agency is in the lowlands. The essay discusses the relevance of the modern nation as the most salient context for understanding minority ethnicities, reviewing research that reveals the translocal foundations of minority ethnicity and the origins of the modern state itself in the networks maintained by ethnic groups across national borders. It finds that the transborder identities of Vietnam's "ethnic minorities" are not necessarily unprecedented, based in crisis, or threatening to the nation-state project. It also challenges the prevailing social scientific preoccupation with the state and with the discipline 
of ethnology by examining research that listens to the voices of ethnic minorities and those of significant non-state actors.

\section{Change and Coexistence in the Uplands}

A recurring theme in studies of Vietnam's ethnic minorities has been the intensity of pressures to which these peoples have been subject over the last half century and the consequent powerful transformation of traditional ways of life. These results have been brought about "collaterally," as a consequence of sustained military conflicts taking place in their traditional homelands; they have been purposefully induced by state development programs; they also entail the intended and unintended effects of the massive social and economic reorganization of the regions where they live. Small, diverse, distinctive, and relatively insular cultures have been violently exposed to the wider world, reformed according to externally imposed standards, and overwhelmed by newcomers and new institutions. The main difference of opinion running through this literature is between the state and its critics. Do such changes represent the emancipation of minority peoples from traditional backwardness, or the tragic loss of their autonomy, cohesion, and cultural distinctiveness?

In describing such developments, foreign scholars have paid most attention to the ethnic groups living in the hills in the center and north of the country. Works by Georges Condominas, Jacques Dournes, and Gerald Hickey, scholars who each conducted prolonged ethnographic research in the Central Highlands, document the devastation unleashed on the highlands during the Vietnam War and its aftermath, and the dislocation, disordering, and disintegration experienced by the region's many small-scale, formerly culturally distinct peoples. These developments also laid waste to the environment of a region in which people once lived in time-tested harmony with nature. ${ }^{l}$ The situation of the peoples of the northern uplands has been described in similarly apocalyptic terms. In the view of Neil Jamieson, Terry Rambo, and coauthors, the principal reasons for the crisis they detect in these areas are socialist and postsocialist development programs. The degrading of the uplands environment due to overpopulation, and the marginalization of ethnic minority groups within broader cultural, economic, and political structures have undermined livelihoods, reduced the salience 
of traditional forms of knowledge, and decreased the relevance of local languages and cultural standards. ${ }^{2}$ More recent studies on the Central Highlands focus on the adverse effects on the indigenous peoples of mass migration to the highlands, official cultural engineering projects, and economic liberalization. ${ }^{3}$ A common thread running through all of this scholarship is the recent arrival on the scene of external agents of extraordinary potency, be that the US military, the communist state, or the market, which possess the ability to wreak havoc or effect change to an unprecedented degree.

These authors caution that it would be a mistake to see the people of the highlands as having formerly been entirely disengaged from relations with the outside world. And yet their works are replete with images that contradict this. Condominas described the kin-based society of Sar Luk as a self-contained cultural world whose horizons did not extend beyond the confines of the village. ${ }^{4}$ For Hickey, each highland society formed its own social system marked by functional relationship between the different elements of religion, settlement patterns, economic activities, kinship, and leadership. ${ }^{5}$ As the clouds of war gather ominously, he sketches a Rousseauean portrait of simple and hospitable highlanders living in elegant harmony with nature. ${ }^{6}$ Rambo, Jamieson, and their collaborators maintain that the northern uplands communities they studied were, until recently, autonomous and closed self-regulating systems, guided predominantly by local knowledge and traditions. ${ }^{7}$ The identities of the highlanders are defined in terms of innate differences with the ethnic majority and difference between upland and lowland cultures. Such approaches resonate with influential scholarly depictions of the tribal groups and indigenous peoples throughout Southeast Asia, as once autonomous, ecologically self-contained societies that are now endangered by the modernizing reforms of national governments. ${ }^{8}$ Ironically, such models have informed the official development project in Vietnam, which is presented as a task of raising awareness of the outside world among minority groups, connecting them to markets, and overcoming their autarchic and backward-looking tendencies. Tourist agencies also profit from this perspective, preparing their clients for an encounter with "ancient" cultures and "a fascinating mosaic of hill tribes" living in the country's "most wild and inaccessible" parts. ${ }^{9}$ 
When outsiders impinge on these isolated worlds, the effects are invariably destructive or all-transforming. Condominas coined the term "ethnocide" in reference to the catastrophic effects on the Mnong Gar's culture of the war, their forcible relocation, and the destruction of their villages. ${ }^{10}$ His two classic ethnographies are cited by many scholars as moving elegies for a vanished way of life. ${ }^{11}$ In Shattered World, Hickey relates the effects on once aloof and sustainable highland societies of a series of increasingly destructive interventions: French colonial economic penetration, South Vietnam's assimilation policies, the war, and finally and most harshly, communist rule. ${ }^{12}$ Jamieson, Rambo, and their team similarly contend that the incorporation of North Vietnam's highland worlds into a wider cultural community has created a cultural crisis for traditional peoples who are now assailed by self-doubt and suspended in limbo: traditional no longer, but not yet modern. ${ }^{13}$ The language of crisis that pervades all these accounts assumes peoples and cultures that are unable to cope with interactions, maintain continuity, or undergo change. Tradition has no traction in the newly encompassing economic, cultural, and political systems in which these groups now live.

Critics of official development policies for ethnic minorities place a great deal of weight on the role of official visions and (mis)conceptions. For example, Hickey regards the Republic of Vietnam's sedentarization policies for the highlanders and its program to settle lowlanders in the hills as elements in the state's strategy to suppress the communist insurgency. Sedentarization was based in the desire for modernization or, at least, the appearance of modernization, with the creation of "model villages" for the lowlanders and highlanders to share. But he also sees the program as an exercise in assimilation, driven by ethnocentric attitudes toward so-called nomadic peoples, their supposedly "wasteful" practices of swiddening, and the presumed lack of a land tenure system. He finds clear resonances with practices utilized by the precolonial court to further Vietnamese southward territorial expansion. ${ }^{14}$ Jamieson and Rambo see the official orientation toward swidden agriculture as based in ethnocentric assumptions about the ways of life of those living in the hills and erroneous ideas that their livelihood practices were environmentally destructive. ${ }^{15}$ As several authors argue, indeed, it is often not the minorities but other interests that are most to blame for the destruction 
of the upland forests. Charles Keyes, too, views sedentarization programs as "based less on economic considerations than on the desire of modern Southeast Asian governments to have all their subjects live in settled communities where they can be controlled by state institutions." 16 Oscar Salemink refers to the fixed cultivation and settlement program as a form of "governmentalization," a way of "making an elusive population more accessible to the various disciplinary strategies of state power." 17

However, as Pamela McElwee notes, the state has significantly failed to implement this vision, with less than a quarter of the 3.1 million people who have been targeted under the sedentarization program actually resettled in permanent villages. ${ }^{18}$ This failure came down to basic economic and political realities, such as the lack of sufficient resources to support the infrastructure required for such ambitious resettlement schemes. Salemink also mentions the decentralized nature of power in Vietnam, whereby local officials interpret the regulations as their own interests dictate. James Scott has analyzed the failure of similarly grandiose state projects elsewhere: ultimately it was the unrealistic nature of the state's own rationalizing vision that caused the demise of such programs, ${ }^{19}$ although this is cold comfort for those highlanders who lands had been lost and traditional settlements broken up in the process.

Interestingly, given this critique by foreign scholars of the Vietnamese state's defective vision, the Vietnamese state's agents have themselves consistently identified a different factor behind their failure to implement this scheme: the recalcitrance of the ethnic minorities, who continued to practice their "backward" and "ignorant" ways in adherence to "outmoded" traditions. This is scarcely a positive assessment, but it does begrudgingly concede agency to the minorities for their ability to frustrate the well-meaning efforts to assist them. The official preoccupation with the recalcitrance of ethnic minorities belies the positive reports routinely delivered about the successful realization of state development objectives. This preoccupation contrasts with that of foreign scholars who, for the most part, remain fixated on the state as the most influential actor in this drama.

Nguyễn Văn Chính's contribution to this special issue contests the thesis put forward by both the state's propagandists and its critics that policies for minority farmers, in particular the sedentarization program, have totally 
transformed the lives of the Kmhmu. State policies filled with transformative intent were far less effective than is usually credited. Socialist democracy reforms did away with traditional forms of dependency to Thái tributary lords, only to be replaced by seemingly new forms of economic dependency, such as farmers' indebtedness to those Thái and Kinh who supply them with usurious financial and capital loans. The policy to fix swiddeners in permanent settlements also failed, as individual families and sometimes entire settlements have continued to relocate in response to not-unfamiliar upland contingencies. State programs to educate the Kmhmu and to reduce poverty among them have been even less effective; meanwhile, new descriptions of the highlanders as "backward" and "ignorant" have taken the place of older pejorative references to them as "slaves" or "nomads." With a state unable to realize its own vision of well-being for the highlanders - indeed, with policies that made life much harder for them - the Kmhmu have drawn upon their own repertoire of knowledge and strategies to address problems not so different from those faced in the past. Nguyễn Văn Chính argues that such traditions are put in play in a context of continuing problems and contemporary dilemmas faced by these upland farmers. To call their strategies outmoded or to celebrate them as traditional survivals is to underestimate the magnitude of the contemporary problems to which they respond.

Another issue receiving the attention of scholars has been the mass migration of lowlanders into the hills. The effects on highlanders of this huge population movement are often assumed to have been great and highly adverse, although research on this issue is thin. Several good studies describe the official resettlement programs and spontaneous migration into the hills, although the focus of this research has been largely on the migrants themselves. ${ }^{20}$ With regard to the impact on the indigenous highlanders, strong language has been used to describe the process-for example, "internal colonialism," "Vietnamization," and "assimilation" - yet the evidence for such claims is invariably impressionistic, and those who advance them admit the difficulties of obtaining good data. ${ }^{21}$ For example, Rambo and Jamieson attempt to link migration from the lowlands to the undermining of highlanders' identity and self-confidence, and to the demonstrations for land rights that took place in the Central Highlands in 2001; their conclusions, although plausible, remain speculative. ${ }^{22}$ Assertions that have been made 
about the "bitterness" and "hardship" experienced by indigenous minorities as a result of this program are not supported by evidence. ${ }^{23}$ Despite the marked tendency for judgments on this question to run well ahead of the evidence, the few available empirically nuanced studies on the problem do support the contention that highlanders have been destabilized and marginalized as a result of the resettlement policies and related programs. ${ }^{24}$ Yet no systematic ethnographic research has been conducted on the interactions between migrants and highlanders, or on these different groups' perceptions of each other. ${ }^{25}$

Therefore, McElwee's study in this special issue is especially valuable, for it examines the relations between indigenous locals and recent migrants in the Annamite mountains. The official policy of mobilizing lowlanders to migrate to the hills has been predicated on a notion of the insularity and backwardness of highlanders, with migration by the ethnic majority Kinh viewed as a means of uplifting the locals, through beneficial interactions with the lowlanders, in a process depicted by the state as one of fraternal solidarity. Undertaking research among both Kinh migrants and indigenous locals, McElwee found relations between these groups marked not by solidarity but by prejudice, tension, and inequality. Predictions that groups might harmoniously interact or merge are belied by the assertion of cultural boundaries between groups and practices of residential separation. Far from erasing ethnic prejudices, commercial interactions accentuate mistrust of others, as old-time residents see the newcomers as stingy and deceptive, while newcomers view the locals as simpleminded and ignorant. Reliance on forest resources characterizes the diverse household economies of new and old inhabitants alike. However, these livelihood strategies are strained by increased pressure on these resources due to overpopulation and enclosures of the forest for state nature reserves. And they are marked by unequal access to commodity markets, with Kinh emerging as the main beneficiaries, despite the fact that highlanders continue to be blamed for destroying the forest. In another ironic twist, cultural transmission does not go as planned. Certainly highlanders adopt lowland rice; however, Kinh unexpectedly turn to swiddening. However, as cultural forms associated with the lowlanders gain ascendancy in upland villages, elders bemoan the weakening of cultural traditions and the disinterest in traditions they detect among the younger generation. 
The strongest example of ethnic minority agency examined in the scholarship is minority ethnonationalism. Hickey locates his groundbreaking analysis of ethnonationalism among the Central Highlanders in the context of state development policies of forced assimilation, interethnic frictions, and social inequities in the highlands. The Bajaraka movement, formed in 1958 and led by young educated highlanders who had greater contact with mainstream society, aimed to overcome the perceived marginalization of highlanders in their interactions with the state and lowland settlers. The FULRO movement that succeeded it in 1964 and joined forces with Cham and Khmer Krom ethnonationalists with ties to Cambodia was more militant, engaging in armed uprisings against the Sài Gòn regime. ${ }^{26}$ After the end of the war, this militant ethnonationalist movement continued its opposition, directed at the socialist regime, and was suppressed militarily only in the early 199os. Salemink argues, too, against the idea that the overwhelming of the Central Highlanders by socialist cultural reforms, migration, and the intensification of market relations might simply lead highland societies to unravelling and aimlessness. Instead he contends that through their conversions to Protestantism, these marginalized groups have reclaimed some measure of autonomy by redrawing the ethnic boundary between themselves and the state. ${ }^{27}$

However, these approaches hold something in common with the state's own critical views of minority agency as past-regarding, divisive, or premised on separateness. This model is antagonistic and finds agency among minorities only in acts that maintain their distinction from the mainstream, or their rejection of the system. By contrast, Thomas Sikor's research into northern Vietnamese Black Tai communities reveals that local dynamics entail a complex intersection of state and nonstate agency, traditional and nontraditional concerns, and local and extralocal factors. While not repudiating the idea that Black Tai society has been affected by state development policies and global market relations, Sikor demonstrates that these local highland actors share a degree of coauthorship in the changes that are reshaping their communities. ${ }^{28}$ Trần Thị Thu Trang's studies on the Mường are similarly attentive to forms of local agency that are not necessarily antipathetic to state power nor necessarily representative of a unified Mường condition..$^{29}$ Jennifer Sowerwine shows how Dao (or Yao) people's cultivation of cardamom and 
medicines for lowland markets undermines dominant conceptualizations of the highlands as fundamentally separate from the lowlands, or as resistant to change. Their modified cultivation practices creatively respond to changing market demands while drawing upon specialized ecological knowledge that lends their adaptations a degree of sustainability. Highlighting the diversity of Dao experiences and their flexible approach to contingencies, her findings call into question representations of upland peoples as overwhelmed by the historical intensification of relations with the outside world, or alternatively as impervious to it. ${ }^{30}$

In their contribution to this special issue, Stan Tan and Andrew Walker offer a wider, regional view of these questions, demonstrating that enduring perceptions about highland minority peoples as isolated, powerless, or resistant to change are not unique to Vietnam. Their comparative discussion of scholarship on the highland societies of Thailand and Vietnam challenges the common tendency to conceive of the highlands as distinct from the plains. One commonality in the portrayal of the highlands in Thailand and Vietnam is to regard cultural identities among the people who live in the hills as fundamentally timeless, and change as externally induced and invariably resisted. This viewpoint is contradicted by the dynamic and shifting character they observe in a variety of culturally iconic features of highland life, including ethnic labels, livelihood strategies, and clothing and housing styles. They also argue against the assimilation/resistance dichotomy that pervades much of the scholarship on highlands societies, observing that it is simplistic to construe lowlands culture or central state institutions as "diffusing" into the hills. Not only does such a perspective construct highland societies or ecosystems as isolates. It also denies agency to highlanders who, they argue, are actively involved in the reshaping of contemporary institutions in the hills. In place of a problematic model that sees culture or power as diffusing upward from a preexisting center, they call for a new approach to state formation in the highlands as a "process of localized genesis, in which the state form is reshaped as it asserts its claims on the frontier."

These new studies' distinctive contribution is their attention to the agency of ethnic minorities in the context of their incorporation into broader processes. Yet their focus on the ethnic groups who live in the uplands of Vietnam does little to unsettle the not-uncommon stereotype that ethnic 
minorities are to be found only in the hills. According to such a perspective, the minorities owe their survival to a given topography, ecology, or sociopolitical remove, conditions that are now being eroded by the advance of the state, the market, or the movement of people. One way to move beyond this proposition is to consider the case of the Mekong Delta, the country's lowestlying region yet also among its most ethnically diverse, where live some of its largest "minority" groups, the Khmer, Chinese, and Cham. There one can see the persistence of vibrant ethnic communities despite a long history of state institutional consolidation, massive immigration, intensive resource extraction, and integration into global commodity markets. These factors have not led to a dissipation of ethnic identities but are connected to their reproduction and unmistakable vitality.

Insights drawn from the new scholarship on the highlands enable us to fathom how this seemingly paradoxical ethnic diversity has been maintained. The ethnic groups of the Mekong Delta engage in diverse livelihoods across a range of complementary niche economies, practice strategic mobility, and draw upon translocal networks - sustaining themselves, as they have for many years, in ways that run counter to the unitary vision for development that is promoted by the state. ${ }^{31}$ Processes of migration and the intense interculturalism between the region's many peoples have sharpened, not diminished, ethnic consciousness and the reproduction of ethnic borders. ${ }^{32}$ These groups are sustained culturally, socially, and materially through religiously mediated communal institutions that span temporal political borders and enjoy a degree of local legitimacy that the central state is hard pressed to equal. ${ }^{33}$ Research on ethnic groups in the Mekong Delta is in a nascent stage, yet I submit that understanding this region may help us to imagine a future for ethnic minorities in the highlands, notwithstanding the intensification in both regions of processes that are often considered adverse to the survival of ethnic minority identities, be they state development interventions, immigration, or integration into global markets.

\section{Minorities beyond Borders}

In considering the reasons that underlie the extraordinary ethnic diversity of Vietnam, few scholars, if any, would dispute the direct bearing of the consolidation of the nation-state on the maintenance of such diversity. Some of 
the approaches reviewed in the previous section attribute the distinctive cultural identities of minority ethnic groups to their traditional autonomy and isolation, yet view the ascendancy of national institutions among these once isolated groups in differing ways. One has the cheerful view of some representatives of the state who construe official reforms of traditional livelihoods, settlement patterns, rituals, and customary practices as inevitable modernization, with the state acting obligingly as midwife of progress. Counterpoised to this perspective is a more critical, indeed claustrophobic, vision of the fate of ethnic minorities, whose identity is imperiled as they are subsumed within the nation-state.

More recent scholarship interprets the seemingly "traditional" practices maintained among minority ethnic groups as strategies that address contemporary challenges, situating the present-day articulation of ethnic identities in the context of intercultural exchanges and frictions. While some scholars detect a certain amount of resistance to the ascendancy of national institutions, or the coauthorship of change in dialogue with the state, none of these approaches discounts the importance of the nation-state as the context in which such interactions are taking place. Despite key differences in explanatory focus, in each of these visions the reproduction or transformation of ethnic minority identities takes place entirely within national space.

A different view does not take these group identities as given but recognizes them as modern entities constructed in tandem with the emergence of the nation-state. According to Ben Anderson, the "minorities" of Southeast Asia were created through the exercise of such late colonial tools of governance as the census and ethnographic survey and were invested with values that reflected the preoccupations of the ruling authorities. The space of the nation was imagined as bounded, and ethnic minorities were incorporated as its subjects. ${ }^{34}$ Taking up this line of analysis, Salemink argues that the "tribal" identities assigned to the Central Highlanders in the colonial period were a refraction of strategic struggles for dominance. Once amorphous groups were "territorialized" and "ethnicized" to serve the imperatives of state power. Today they are folklorized and aestheticized in museum exhibits, festivals, and cultural performances, made into contemplative figures that reflect back to the state its vision of the nation as a multicolored "flower garden" or "mosaic" of ethnic cultures. ${ }^{35}$ When minority groups sing 
and dance, they dramatize the geopolitical imaginary of the multiethnic nation. ${ }^{36}$ Here, the nation-state looms even larger as the very condition for existence of minority ethnicities, providing the language, categories, and contexts in which their identity can be imagined.

Today, however, the most influential depiction of ethnic minorities is the view of them as developmentally disadvantaged. As no shortage of official development reports attest, the ethnic minorities are disproportionately represented among the nation's poor and hungry. ${ }^{37}$ Today poverty, measured as low levels of household monetary expenditure, is widely considered to be virtually synonymous with minority ethnicity. Equally pervasive is the view that they are disadvantaged by remoteness, living far from the center of life, in the mountains and along the nation's fringes. And their "cultural level" is terribly low; they are illiterate in Vietnamese, unschooled and "unaware" of what is going on in the outside world. ${ }^{38}$ Ubiquitous poverty maps that adorn the walls of international development agencies show poverty to be most concentrated in the regions where ethnic minorities live in greatest numbers, in the regions far from the center, where Vietnamese cultural institutions are at their weakest. What these depictions do not map are the wealth of livelihood strategies, ties of reciprocal obligation, mutual support networks, or cultural standards and competencies to which these ethnic Others have recourse, which are key to their survival and form the very stuff of life. ${ }^{39}$ Such depictions lend full weight to an arbitrary national notion of wellbeing, according to which to be developed is to be fully monetarized, living in the lowlands, and fluent in Vietnamese. These criteria for development affirm the lowland majority group as the center, the cultural standard and model for all ethnic groups.

These modern depictions of the ethnic minorities, with their multitude of gross disadvantages, overlap uncannily with the premodern vision in lowland Vietnamese courts of those cultural Others who lived in the inhospitable mountains and fringes of civilization, as barbarians [man], savages [moi ] , and uncultured beings. One might readily surmise that poverty has become the new barbarism, illiteracy the new savagery, remoteness the new wildness: that development is nothing other than new rhetoric for age-old chauvinistic and paternalist assumptions. Despite the fact that international development agencies provide most of the scientific capacity and the concepts 
for calculating the disadvantages of the minorities, it is tempting to conclude that nothing has changed other than the capture of an international development bureaucracy and its impressive array of measurement instruments by an unreconstructed or renascent feudalism. This is neo-Confucian statecraft brought to you by the United Nations.

Of course, a different view of history is that political power in Vietnam has always been a function of an elite group's preferential access to a particular set of translocal economic, cultural, and technological resources through which the polity has been established and its cultural diversity imagined. Hence the transnational lens through which ethnicity in Vietnam is regarded is not news to historians of Vietnamese statecraft. ${ }^{40}$ Yet scholarly observers of Vietnam can be faulted for confining most of their attention to a sole set of translocal linkages - those entertained by lowland elites with China - at the expense of the great variety of linkages that connect other groups within the present-day territory of Vietnam with other points on the compass. $^{41}$

One of the biggest challenges to the official (trans)national project of multiethnic governance today comes from minority groups who, on the grounds of their unique religion, customs, or origins, assert their distinctiveness from the Vietnamese nation and express the desire for autonomy from it. The Degar Christians of the Central Highlands are one such group, but as their case has been discussed elsewhere, I focus on another group, the Khmer Krom of the Mekong Delta. ${ }^{42}$ Asserting that they are the indigenous people of southern Vietnam, the Khmer Krom represent the state's project as a colonialist enterprise, bent upon obliterating their historical consciousness, language, and culture. Like the Degar Christians, religious freedom and land rights feature among Khmer Krom demands, although the crux of Khmer Krom demands is recognition of precedence and of Cambodia's historical sovereignty over southern Vietnam. Another comparison with the Degar movement is its transnational underpinnings. The Khmer Krom derive material and intellectual support for their claims from beyond the nation's boundaries. Due to restricted opportunities for expression in Vietnam, their most vocal leaders reside and promote their case outside of Vietnam and derive support from diasporic populations in the United States, Canada, France, and Australia, as well as in Cambodia. In addition to their own 
advocacy organizations, based in several countries, they have representation in international bodies such as the Unrepresented Nations and Peoples Organization and the United Nations Permanent Forum on Indigenous Issues. They maintain contacts with other indigenous groups in these international forums and also lobby individual governments to call for the enforcement of international standards such as the UN Declaration on the Rights of Indigenous Peoples and the UN Human Rights Convention. Intellectually, they derive inspiration for their self-representation as indigenous, unrepresented, and colonized peoples by drawing analogies with the plight of Palestinians, Australian Aborigines, East Timorese, and with the Vietnamese themselves in their struggle against French colonialism. These claims and identities are widely known among the Khmer population in Vietnam, thanks to the passage of people into and out of Vietnam and the group's effective use of the Internet, cell phones, and radio broadcasts to communicate with people inside the country. ${ }^{43}$

However small and powerless they may be at present, these transnational minority movements are regarded by some as among the gravest challenges to the current official model of national multiethnic governance. Foreign scholars see the surge in affiliations to "world religions" and of ethnonationalist sentiments in recent years among the groups along Vietnam's national periphery as a response to the disordering impacts on ethnic minorities of state minority policies and the more recent official promotion of market-oriented development policies. ${ }^{44}$ These transnational identities and affiliations, be they Christian conversions, Muslim reformism, or ethnic irredentism, are symptoms of the corrosive, self-defeating nature of the current model pursued by the state. These is little doubt that the claims for better treatment of minorities that emanate across national borders rattle the Vietnamese authorities, who frequently resort to desperate rhetoric to describe them. The authorities recycle the language once used by the party to mobilize much of the populace in its postcolonial wars, regarding such claims as an assault on the nation's sovereignty by hostile foreign forces and as a threat to national unity. In an effort to attract sympathy for its case among new allies in the international system, the foreign ministry has adopted the terminology of US neoconservatives in labelling demonstrations in the Central Highlands in defense of minority rights as acts of "terrorists." 45 
Concern about "hidden hands" is evident in government rhetoric about protests staged by the Degar Christians and, more recently, the Khmer Krom, and their demands for autonomy, religious freedom, or respect for their culture, which are attributed to the subterfuges of overseas reactionaries and hostile foreign forces seeking to sabotage national unity and foment unrest. ${ }^{46}$

Yet there is another way to see these attempts by minority groups to reach out across borders in promotion of their worldview and defense of their rights. That is, in many cases they give voice to ethnic groups whose crossborder links predate the formation of nations in Southeast Asia. Several such groups maintain social networks that were never effectively dismantled in the process of multiplication of nations in the region and share a common language, tradition, autonomous origin myths, and history that have not been fully merged into the national voice. Recent ethnographies by Sarah Davis on the Thai Lue in southeast China and by myself on the Cham Muslims of the Cambodia-Vietnam border trace transnational movements and cross-border networks of minority groups that each span more than one national boundary. ${ }^{47}$ In their contemporary journeys across modern borders, the Thai Lue and Cham Muslims follow premodern circuits and networks that existed prior to the delineation of national territories. The contemporary effervescent "postmodern" revival of identities among such groups relies on globalizing technologies and benefits from new national "open door" policies, yet also draws upon much older traditions of religious travel between a network of linked communal religious institutions that formed the infrastructure of a prenational transregional identity. As in the past, material support for the consolidation of household economies and local communal institutions is derived from this translocal network, and contemporary passages across borders draw on historically constituted practical capacities such as multilingualism, the arts of travel, and accumulated knowledge of places on different sides of a given border.

Such insights pose a challenge to views of the contemporary transnational identities of "minority" ethnic groups as novel, destabilizing, or motivated primarily by unprecedented levels of desperation. Not all of these translocal, cross-border identities and affiliations are recent; many have a long history, even though the identities and methods of communication 
may today take new forms. It would be insufficient to regard such transnational affiliations exclusively as responses to unprecedented levels of desperation, since these translocal affiliations have long been key to the economic and cultural sustenance of many such groups. It would be inadequate to view them solely through a political lens as undermining the security or unity of the nation writ large, since the transnational strategies that are used to enrich and secure a host of localities have paralleled the rise of national institutions and continue to bring wealth and security to these localities in a manner that is complementary to the state's development goals, even if such sources of security and well-being are not understood or acknowledged by the state's agents. Most fundamentally, this perspective challenges views of Vietnam's ethnic diversity as an effect of isolation, remoteness, and separation or as stage-managed by the state, since the cultural diversity that some observers fear to be threatened in an age of globalization, or credit to the state, is produced out of such transnational movements, connections, and interactions.

The case of the Hmong helps to illuminate what is distinctive about this approach. Their situation appears to show that the social, economic, and cultural marginalization of some groups might be so great that the only imaginable solution to their dilemmas is to opt out of the nation altogether. The Hmong "rank” very badly in Vietnam's (trans)national socioeconomic development indicators, with low literacy in Vietnamese, weak schooling, poor access to health, and high levels of poverty. ${ }^{48}$ Their involvement in customary economic and ritual activities is seen by state officials both as cause and effect of their poverty, and these practices are subject to intrusive surveillance and reform. Seemingly in response to their poverty, the uprooting of their traditions, and a sense of alienation from the national culture, the Hmong have been highly receptive to overseas Christian proselytizing, converting in large numbers to evangelical Christianity. ${ }^{49}$ Government anxieties about such alliances are clear. From an official perspective, the Hmong are a governance headache, being a mobile, cross-border community, aloof from the national culture, "uneducated" and therefore easily duped by the overseas missionaries who proselytize via short-wave radio, and potentially threatening to national interests. The Hmong appear to dramatize the options and dangers facing many poor and marginalized minority 
groups who, in seeking salvation through transnational connections and autonomous identifications, potentially elicit a repressive response from the state.

The article in this special issue by Sarah Turner and Jean Michaud offers a way out of this dilemma by shifting the focus from the development indicators and localizing tropes that dominate studies of minorities in Vietnam to instead explore the livelihood strategies of the Hmong within the context of their distinctive translocal historical tradition. Renowned today for their sales of colorful fabrics in the Sa Pa tourist marketplace in northwestern Vietnam, the Hmong of Sa Pa are transnational textile traders, who cross the Chinese border to make purchases and produce textiles for sale to domestic exporters and visiting tourists. Their contemporary trading practices belong within a historical tradition of flexible adaptation to contingencies, imaginative exploitation of available economic niches, and selective diversification of livelihoods, which, in the past, have included swiddening, opium growing, and the gathering of forest resources. Such flexible and imaginative strategies have not greatly enriched the Hmong in Vietnam, but they have permitted these marginal actors to evade absorption within Vietnam's centralizing state and avoid potentially even greater marginalization. As displaced people with no particular nation to call their own, the Hmong play to their advantage their traditions of mobility, kin-based social structure, and economic adaptability to survive, retain a degree of autonomy, and reproduce their distinctive way of life.

The ethnic Chinese, who reside predominantly in southern Vietnam, lie at the other end of the imagined spectrum of economic well-being. They are considered to be economic high achievers, possessed of commercial acumen, and are associated with prosperous urban living. So highly rated are they by the government that they are frequently tabled alongside the Kinh in socioeconomic rankings that separate this pair from the "ethnic minorities," who are grouped together in a different category lower down the development scale. In a postsocialist era in which many people in Vietnam are embarking on small family businesses for the first time, ethnic Chinese are held up for emulation as the consummate business class. In popular circles in southern Vietnam, their economic success is often thought to be wholly deserved, deriving from hard work, honesty, patience, and piety, as distinct 
from the Kinh, said to be newcomers in business and often said to be engaged in duplicitous and risky practices. Additional prestige derives from their association with China and their reputation for being literate, cultivated urban cosmopolitans. These conceptions of Chineseness are highly idealized, for many ethnic Chinese live in poverty in rural areas of the Mekong Delta, while one will often hear people described as "Chinese," irrespective of the facts, simply because they are wealthy, urban businesspeople. ${ }^{50}$

It will be recalled, however, that Chinese commercial prowess has not always been positively valued. In the French colonial period, the Chinese commercial monopoly and their exploitative practice of usury were thought to be major factors behind the landlessness and impoverishment of farmers. ${ }^{51}$ During the war with France, the Chinese were described as more interested in making a profit by any means possible than participating in the anticolonial movement. ${ }^{52}$ As elsewhere in Southeast Asia, nationalists had a tense relationship with the Chinese commercial minority because of their perceived focus on personal enrichment, sojourner mentality, residence apart in wealthy enclaves, and supposedly apolitical orientation. ${ }^{53}$ After 1975 , Chinese commercial networks and their supposed domination of the economy in the South were described as parasitical and at odds with the interests of the people and the revolution. ${ }^{54}$ Further compounding the perception of the Chinese as aliens was the view that emerged in the context of Vietnam's hostilities with China in the late 1970s - that the Chinese might serve as a fifth column for China. The response to this perception of the Chinese was their mass expulsion from Vietnam in the late 1970s. Curiously, the threat to the nation posed by Vietnam's wealthiest ethnic group is not dissimilar to that of its poorest and most marginal ethnic groups, each of which might draw upon transnational links to pursue agendas deemed to be at odds with the nation.

As Thomas Engelbert shows in his contribution to this issue, doubts about the allegiances of the Chinese minority in Vietnam have a long history, despite the little-appreciated fact that this group's transnational economic networks played a critical role in the bitterly contested emergence of the modern Vietnamese nation. During the French colonial period, as today, the Chinese minority was pivotal in commerce and transportation in 
southern Vietnam and its wider region. The socially and organizationally heterogeneous Chinese population of Cochinchina faced many difficult choices during the First Indochina War, torn as it was between the competing demands of French colonialism and the Vietnamese and Chinese nationalist and communist movements. Trade conducted by the Chinese was indispensable to the multitude of parties involved in the war and forced the major antagonists to alter their policies. Despite their differences with the communist-led Việt Minh, Chinese Nationalist Party members and wealthy urban Chinese traders supplied the Việt Minh war effort, under the ever-suspicious gaze of the French and Americans. Meanwhile, tensions between the Chinese and Vietnamese communist parties, later to erupt into a war between the two nations, were already apparent in their divergent policies for the Chinese population in Vietnam during the First Indochina War. Facing contradictory charges of self-interest and disloyalty from all sides in this complex conflict, the Chinese minority's struggle to make a living and survive the dangerous wartime conditions crucially influenced the outcome of the war and shaped the society of which they remain part in times of peace.

These case studies bring us a long way from prevailing explanations of ethnic distinctiveness as deriving from geographical or cultural remoteness or as a performance orchestrated by the state. An important ingredient missing from such portrayals is the resource comprised by the transnational networks of Vietnam's diverse “minority” groups. A great many ethnic groups in Vietnam derive material and cultural sustenance and reproduce their distinct identities through exchanges with places, centers, and peoples beyond the nation's borders. This is, of course, also true for the ethnic majority, those Việt who call upon ties of kinship, spirit, sentiment, and memory and who mobilize the resources that circulate among members of an imagined community that spans national boundaries. The national project of governing ethnicity is also a transnational project supported by international organizations and foreign scholarship, just as in the past, the revolutionary anticolonial project was sustained by regional Chinese commercial networks, among many other transnational networks. This requires a new conception of the multiethnic nation, not as a "flower garden" with neatly marked borders or as a "mosaic" comprised of discrete fragments of color but as a place 
where a multitude of transnational networks intersect and tangle. The challenges for those who guide the levers of state power are, first of all, to see this multitude of transnational networks, to comprehend it historically and sociologically, and to apply principles of equity and consultation in the task of managing it.

\section{Minority Voices}

A notable achievement of the scholarship on ethnic minorities in Vietnam is its illumination of the rationales of state policy and of the elites who conceive of and execute it. Foreign scholars have paid particular attention to the paternalist inclinations of precolonial, colonial, and postcolonial elites, the evolutionary and unilineal assumptions of socialist and nonsocialist reformists, the ethnocentrism and elitism enshrined in official development programs, and the anxieties about security and authenticity manifested in cultural policies, to cite a few of the main lines of critique. Vietnamese scholars have ventured their own analyses of the rationales of ethnic minority policies - for instance, criticisms of the "divide-and-rule" strategies of imperialists or the feudal and exploitative orientation of former regimes. ${ }^{55}$ Notwithstanding the different emphases, provisionally identified as "foreign" and "local," the value of these critiques has been recognized by many scholars, irrespective of nationality. ${ }^{56}$

Such a focus is welcome and merited. Successive states in Vietnam have not been hands-off in their governance of ethnic minorities, official reform goals have been ambitious, the rationales for policies have undergone major modulations, yet with apparent continuities, and the impacts of such policies on the groups subjected to them are said to be momentous. Hence to understand the worlds of ethnic minorities one cannot dispense with this important research topic.

The negative aspect of this tendency is that the intensity of the scholarly gaze on the state far outweighs the degree of attention that has been devoted to ethnic minorities themselves. This is especially true of anthropological research on or in Vietnam. Compared with research conducted in most other countries in Southeast Asia, ethnographies that describe the worldviews of Vietnam's diverse ethnic peoples and that ground these outlooks within the contexts of people's histories and everyday lives are in precious 
short supply. Very little long-term fieldwork has been conducted in the naturalistic life settings and in the languages of the peoples studied. Archival research, statistical surveys, interviews with policy makers, and officially monitored flying field visits to the localities under investigation dominate the evidentiary base. Very little ethnographic work has been done on the consequences of state policies; hence, our knowledge about the intentions of these policies is much better than our comprehension of their effects. Additionally, there has been a notable lack of attention to the nonstate actors who interact with minority peoples, such as traders, real estate speculators, tourist agencies, commercial culture brokers, and settlers, or to the intercultural contexts in which ethnicity is practically at stake every day, such as the marketplace, the shrine, the plantation, the factory, the police station, the school room, the army, or the city.

When anthropological field research was in its zenith internationally from the 1950 s to the 1980 , the areas of Vietnam where most ethnic minorities reside were virtually inaccessible to professional fieldworkers because of war, strained international relations, and security concerns. ${ }^{57}$ The contemporary focus on the official worldview may be due to continuing difficulties of access to field sites faced by both domestic and foreign researchers, researchers' awe of the potency of the Vietnamese state, the ingenuity of state agents in capturing research, and a prescriptive turn in both Vietnamese domestic and foreign anthropology toward studying the power holders as an inherently valuable project. Yet, consequentially, I would identify two distorting and quite possibly unintended effects in the anthropology of Vietnam's minorities in the postwar context. First, in what stands for anthropological research, the voice of the state substitutes for that of the ethnic minorities. Second, the state emerges as uniquely potent, coherent, and effective. Such conclusions, although they may indeed please some in the Vietnamese leadership, are scarcely tenable, since they have yet to be substantiated by ethnography, social history, or the people in whose name the policies, and sometimes the research, are carried out.

Yet to my mind the most remarkable feature of the scholarship on ethnic minorities in Vietnam is its focus on Vietnamese ethnologists as objects of inquiry. Many scholars have mined this topic, beginning with a paper by Grant Evans on Vietnamese communist anthropology - a theme tenaciously 
pursued in his subsequent studies. ${ }^{58}$ This has been followed by book-length histories - by Salemink on the ethnography of the Central Highlanders and by Jean Michaud on missionary ethnographers in Tonkin and Yunnan. ${ }^{59}$ Other substantial works include Patricia Pelley's discussion of the role played by Hà Nội-based historians and ethnologists in the stabilization of the official notion of the multiethnic nation; ${ }^{60}$ Keith Taylor's account of the emergence of the ethnic category "Mu'ơng"; 61 Susan Bayly's study of French colonial ethnography and its intersections with nationalist agendas; ${ }^{62}$ Charles Keyes's paper on the nature of the ethnological classification project; ${ }^{63}$ and Priscilla Koh's review of Vietnamese ethnology in the Đổi Mói period. ${ }^{64}$ Vietnamese anthropologists have been no less fascinated than their foreign counterparts in the life and times of their disciplinary predecessors in Vietnam and have produced numerous studies on this topic. ${ }^{65}$

Herein is a veritable treasure trove on the contexts in which ethnographic knowledge is produced. Ethnology in Vietnam, so it would appear, has had a robust and remarkably complex intellectual history, with the discipline emerging out of colonialism, shaped by nationalist and revolutionary movements, deployed in military conflicts, reformulated in complex postcolonial political contexts, and infused with a variety of ideological currents including neo-Confucianism, social Darwinism, nationalism, socialism, and neoliberalism. These studies of the life and times of ethnology in Vietnam make a unique contribution to knowledge of the intellectual environment of Vietnam.

Yet if we limit ourselves to foreign language publications of the last few decades, we find that the knowledge accumulated about the ethnologists who specialize on Vietnamese minorities eclipses that about the minorities themselves. Again, I underline the serious dearth of basic ethnographies. If ethnographic research from the mid 1940s to the mid 1970s was, at best, fragmentary, during the three decades that followed the end of the Vietnam War not a single ethnographic monograph on an ethnic minority community in Vietnam was published by a foreign anthropologist based on research conducted during that period. Not unlike its neighbors Laos, Cambodia, and China, where access to ethnic minority communities has been equally hard for ethnographic fieldworkers, the minorities of Vietnam are among the least studied peoples on earth. This being the case, the contemporary vogue to 
study the scholars, rather than the people, risks leading the discipline down more than one blind alley.

Some may well be of the opinion that the study of anthropologists by anthropologists, which twins the study of historians by historians, is altogether far too comfortable an arrangement, an effete and inbred pursuit. While this vogue follows the reflexive turn in anthropology internationally, the deficiency of fundamental ethnographic work in Vietnam has generated precious little material for this rather crowded field of reflexively minded anthropologists to pick over, making this pursuit, at best, a hollow echo of the international trend. Such a research agenda in fact risks creating the misleading impression that, in Vietnam, ethnography is more robust and ethnographers more influential than may actually be the case. It is not a little ironic to see the flourishing of this agenda today, given that that never before have conditions (regarding fieldwork funding, accessibility, and safety for researchers and their respondents) been so favorable for ethnographic research. And if the minorities of Vietnam are indeed experiencing serious depredations to their way of life under the influence of official ethnological models, as many of these scholars claim to be the case, it is nothing short of tragic that such a great share of the limited and unequally distributed resources available for doing anthropological research is given over to such pursuits rather than to investigating what is actually going on and coming up with some solutions.

The focus of Vietnam's ethnologists faces similar serious questions of relevance. Since the late 1950s, the major game in ethnology in Vietnam has been the project of ethnic classification. ${ }^{66}$ This official pursuit, like that of most foreign anthropologists who ostensibly write about ethnic minorities, is not grounded in extended participant observation in local contexts and does not address the reality of how people represent themselves. It is not at all certain that the categories and group identities promulgated by these scholars are even known, let alone utilized, by people in their multifarious interactions within or beyond the groups to which they have been assigned. Ethnic voices scarcely register in this official research project. In both these bodies of research, scholastic categories are privileged over demotic folk knowledge; texts over speech; formal representations over practice; words over deeds. The contexts of the knowledge under examination are the academy, 
the state ministry, and the published debates of a small international elitenot the contexts of the household, the forest, the field, the market, the temple, or the local government office. And of course in real life these contexts are forever shifting and shifted by people themselves.

The need to exit the loop, to investigate what is happening on the ground, has been voiced by many of the scholars who have pioneered this research agenda. Some today are at the cutting edge of the return to ethnographic research in their own fieldwork practice and are encouraging that of their students. Most notable is the contribution to ethnography made by Vietnamese researchers who have crossed multiple cultural boundaries in studying abroad and learning new foreign languages and methodologies. ${ }^{67}$ In this venture, they have negotiated the intergenerational sensitivities in their own institutes and the bureaucracy in the field. They have built rapport and earned the trust of respondents and experienced the hardships of doing prolonged fieldwork. In writing up they have stuck close to their ethnography. While preserving confidentiality they have given voice to the people who have entrusted their confidences to them and have advanced a view of the world that genuinely issues from the local context in which they conducted their research. To nominate just one example, Nguyễn Văn Thắng's field-based study on the $\mathrm{Na}$ Miểu (officially regarded as Hmong) in northern Vietnam led him to question the assumptions of the official classification project. He found that this group's identity has been situationally shaped in interactions with neighboring groups - via intermarriage, adoptions, and hierarchical relations - as well as in this group's dealings with the state. The Na Miểu also shift between identities, depending on context, in response to expectations and in line with practical benefits. ${ }^{68}$

Internationally, Japanese scholars are leading the breakout from preoccupations with anthropological self-analysis and official classifications. Rie Nakamura's doctoral dissertation on self-identification among the Cham is an important pioneering study. She shows that "Cham" in different parts of Vietnam have resisted official classifications of their ethnicity, some emphasizing their origins in the indigenous kingdom of Champa, others rejecting ethnicity for a religious identity as Muslims. ${ }^{69}$ Masako Ito demonstrates that the identifications "Tày" and "Nùng" in northeastern Vietnam have been historically fluid, and that these identities register historical distinctions in 
migration and sociopolitical stratification, as well as proximity to Chinese, French, and Vietnamese political projects. The labels "Tày" and "Nùng" reflect not only changing official constructions of that fluid reality but also people's own comprehension of their circumstances and their own strategies and alliances. ${ }^{70}$ Japanese ethnographers have also explored the centrality of ritual texts, contexts, and iconic spirits in the constitution of "ethnic" group identity and the process of cultural transmission, some noting a recent transformation in the role of those ritual foci from substantive lived tradition to ethnic marker. $^{71}$

Venturing furthest in this direction, LiAnne Yu examines the dynamics surrounding the identity of the Chinese, or Hoa, in Chợ Lón. Nostalgia for the congregation [ bang] system infuses contemporary efforts to revive traditional forms of associationalism, although its impact is limited to the older generation and predicated on linguistic capabilities. The younger generation identifies with a broader and more diffuse conception of Chineseness that emerged in the postwar context in dynamic relation to Vietnamese nationalism. Premised on her findings that the Chinese community of Chợ Lớn is now transnational, she explores the constructions of identity in the context of multiple imaginary homelands, some of the past, some of the future. And she examines the complex Hoa self-representations in the context of a range of interactions with business sojourners from Taiwan. Yu argues that the perceptions of ethnic Chinese held by Taiwanese businessmen in Vietnam have helped to reshape what it means to be Chinese in Chợ Lớn. The perception that the ethnic Chinese are trustworthy and hardworking informs recruitment practices and interpersonal relationships of this transnational business class. ${ }^{72}$

Dủỏng Bích Hạnh's article in this special issue is based on her doctoral and ongoing research on the changing lives and status of Hmong girls in Sa Pa town. ${ }^{73}$ In their everyday lives in Vietnam, the Hmong have to deal with mainstream perceptions of them that are, at best, ambivalent. Like members of other minority groups, the Hmong are regarded as remote cultural Others: at the same time backward but also, contradictorily, embodying valued traditions that are thought to be threatened by globalization. Yet this is not the only set of views to which they are subject. The reemergence of $\mathrm{Sa} \mathrm{Pa}$ as a tourist destination and as a market for the sale of Hmong handicrafts has 
provided a new set of opportunities and interactions for the Hmong girls at the center of her study. Dủong Bích Hạnh traces these girls' journeys through three stages, beginning with their initial arrival in town, to work as sellers and tour guides, and their introduction to a new, exciting, modern, cosmopolitan lifestyle. After several years in town, their situation is liminal, living arrangements in town are difficult, and their future in the tourist market is uncertain. Some return to the village and marry. Yet those who have remained in town over the years have gained confidence in their dealings with locals and foreigners, obtained securer jobs and lodgings, and strengthened their role as brokers in the tourist trade. They have become cosmopolitans, displaying a facility with foreign languages and ways, and developing meaningful relationships with people from many countries. Their connections, knowledge, and skills are admired and valued by local townspeople, and the girls enjoy a kind of prestige and respect that was not available to them in times past.

Distinctive and important aspects of these studies include their emphasis on popular (nonofficial) constructions of ethnicity, the intercultural contexts in which ethnicity acquires value, and the urbanized settings in which many ethnic minorities in Vietnam today live. Another developing avenue of research along these lines explores the meanings attached to minority ethnicities in the popular religious realm. Thien Do conceives of spirit mediumship as a key means by which the Việt in the South have interacted with ethnic others and accessed their imputed powers. ${ }^{74}$ Goddess shrines are another key intercultural site where the official meanings that attach to ethnicity are reworked, and where the imputed potency of ethnic others is appropriated, authenticated, and emulated. ${ }^{75}$ In a study dedicated substantially to the Cham, I discuss popular perceptions of the Cham and the Khmer in the Mekong Delta, who are widely acknowledged to be masters of the arts of sorcery and exorcism. Popular views of these peoples as powerful sorcerers, all too willing to utilize occult knowledge against their enemies, are dismissed by state officials as irrational, harmful, and divisive. Yet these religious viewpoints can be seen as superior to official knowledge in three ways. They acknowledge the precedence in the Mekong Delta of such groups; recognize their possession of superior cultural competencies; and defer to their power to influence the success of ventures undertaken in their domains. 
This perception, in turn, has influenced both the Cham and the Khmer, whose religious officiants are in high demand as sorcerers and exorcists, and who also patronize these popularly constructed intercultural nodes of spiritual power themselves. ${ }^{76}$

What influence, if any, do such popular registers of knowledge have on the way the state conceptualizes and manages ethnicity? This is the fascinating topic taken up by Oscar Salemink in the essay that concludes this special issue. He examines the neo-Confucian and Marxist underpinnings of official constructions of the ethnic minorities and identifies commonalities in their ahistorical, paternalistic, and disciplining approaches. This official vision is counterpoised to a popular Daoist-inspired conception of the ethnic minorities that imagines them as predecessors and seeks to embody and magically access their powers in possession rituals that both transgress and reconstitute ethnic, gender, and ritual boundaries. Intriguingly, this popular approach has been appropriated by state authorities as they search for new, spiritualized foundations for national legitimacy. The new official approach is to regard the ethnic minorities as "contemporary ancestors," a hybrid Confucian-Marxist-Daoist approach that attempts to ritually embody their imagined authentic Otherness in festivals that enlist the ethnic minorities in the ritual regeneration of the national community. This essay shows that the state's approach to ethnic minorities is not monolithic or unchanging, nor is it the only approach in the society that matters. State policy has changed in a dialogue with popular religious conceptions of the minorities. Whether the minorities accept the new orthodoxy or reposition themselves in relation to it is a subject that only further research can illuminate.

\section{Conclusion: Enlarging the Research Agenda}

This essay takes issue with the prevailing "carceral" conception of ethnic minorities in Vietnam. This conception is evident in the principal alternatives for examining their agency: as peoples whose traditional autonomy has been lost, who have been "freed" from their traditional "backwardness," or who assert themselves only when resisting their incorporation into wider political and economic structures. Existing analyses also "confine" ethnic minorities within the space of the nation-state and as subject uniquely to national institutions, consequently detecting in their cross-border relations 
signs of crisis in their communities or in the nation-state. And the ethnic minorities are deemed to be subjects of a disciplining classificatory project; their voice has been appropriated by others. Against this limited carceral conception of minority ethnicity, this essay and those that follow it conceive of "minorities at large," taking an enlarged view of their capacities for agency, spatial relationships, and representations of their identity made by themselves and others.

Foremost to this new approach is that the agency of ethnic minorities is not insignificant, despite the powerful new social forces reshaping their worlds. Their agency is not only reactive, for ethnic minorities in Vietnam are implicated in the transformations under way in their own communities. This new approach identifies a continuing role for traditional practices and competencies in the modern conditions of a market economy, evolving state policies, and major demographic realignments. It entails, at the same time, an enlarged view of those traditions and a more modest view of the transformative effects of externally generated forces. It is attentive to the modern conditions in which ethnogenesis, boundary marking, and assertions of traditional authenticity occur. Yet it also recognizes that these are not historically unprecedented conditions, and that the contemporary dynamics of ethnicity may have important "premodern" antecedents.

Another major finding is that contemporary transnational affiliations entertained by ethnic minorities are not necessarily unprecedented. Nor are they uniquely a response to crisis, be that the crisis of communities facing intense political and economic interference and societal unravelling, or the crisis of the imperilled nation-state in an era of globalization. Instead, the cross-border exchanges and transnational networks maintained by many ethnic groups are consistent with older translocal relations and efforts to sustain livelihoods and reproduce shared values. These old and new networks, identifications, and competencies do not necessarily threaten national unity or undermine traditional forms of local cohesion, since translocal relations have long been a precondition of the material and cultural well-being of localities in Vietnam, of cultural diversity, and of the existence of the wider Vietnamese polity.

The peoples who today are referred to as "ethnic minorities" undeniably have long been in the eye of powerful outsiders: ranked, "tribalized," construed 
as "undeveloped," or ethnically categorized. And yet the categories of the state and elite scholars are not the only ones that count. People have their own identifications that are often at odds with elite categories, or they may indeed share elite categories for their own reasons. The contexts in which identities are defined are diverse and shifting, as are the registers in which difference is expressed and acted upon. Ethnic differentiation is not the effect of isolation or resistance but is articulated and tumultuously redefined in a range of intercultural contexts. The state and professional anthropologists cannot hope to remain aloof from these contexts as some kind of eternal keepers of the truth. Instead, it is suggested, they will remain relevant only insofar as they engage with the messy demotic contexts, categories, and registers through which ethnic difference is reproduced in this complex and changing society.

These insights are based primarily on ethnographic research, with some notable contributions from social history. Their originality owes not only to the perspicacity of the researchers but also to the fact that these disciplinary methodologies have been, for a very long time, difficult, devalued, and scarcely utilized in the study of ethnic minorities in Vietnam. The findings in this special issue are significant in that they challenge received stereotypes with knowledge that has been gathered by researchers working directly among the communities studied. Nevertheless, despite the many promising leads discussed in this essay, the reported findings are merely preliminary and suggestive. Ethnographic research in Vietnam has far to go, and a great many more ethnographies and ethnohistories will need to be compiled before elementary justice is done to the remarkable richness and complexity of the country's ethnic landscape. However, these essays are pioneering efforts in what one hopes will be the continuing consolidation of ethnographic methodology as a cornerstone of efforts to advance knowledge about the ethnic minorities in Vietnam.

PHILIP TAYLOR is Senior Fellow, Department of Anthropology, Research School of Pacific and Asian Studies (RSPAS), Australian National University. Funding to research this paper was provided by the Department of Anthropology, RSPAS, and Australian Research Council grants DPo665517 and DPo665611. Nicholas Tapp offered insightful comments on an early draft of this paper. 


\section{ABSTRACT}

Reviewing the scholarship on ethnic minorities in Vietnam, this essay identifies problems with the prevailing "carceral" approach that regards ethnic minorities as deprived of agency and as territorially circumscribed, disciplined subjects. New ethnographic and historical research demonstrates, to the contrary, that ethnic minorities have been active in the transformations of their worlds. The new scholarship situates contemporary minority transnational networks in the context of older translocal affiliations, identities, and livelihood strategies. The enduring anthropological preoccupation with official classificatory projects is questioned; instead, attention is given to popular identifications in circulation, and transition, among ethnic minorities and their proximate Others.

KEYW ORDS: ethnic minorities, agency, transnational networks, ethnology, Vietnam

\section{Notes}

1. Georges Condominas, We Have Eaten the Forest: The Story of a Montagnard Village in the Central Highlands of Vietnam (London: Allen Lane, 1977) [Translation of: Nous Avons Mangé la Forêt de la Pierre-génie Gôo (Paris: Mercure de France, 1957)]; Georges Condominas, L'Exotique est Quotidien, Sar Luk, Viet-Nam Central [The Exotic Is Everyday, Sar Luk Central Vietnam] (Paris: Plon, 1965); Jacques Dournes, Minorities of Central Vietnam: Autochthonous Indochinese Peoples (London: Minority Rights Group, 1980); Gerald Hickey, Shattered World: Adaptation and Survival among Vietnam's Highland Peoples during the Vietnam War (Philadelphia: University of Pennsylvania Press, 1993).

2. Neil Jamieson, Lê Trọng Cúc, and Terry Rambo, The Development Crisis in Vietnam's Mountains (Honolulu: East-West Center, 1998); Terry A. Rambo and Neil L. Jamieson, "Upland Areas, Ethnic Minorities and Development," in Postwar Vietnam: Dynamics of a Transforming Society, ed. Hy Van Luong (Oxford: Rowman and Littlefield, 2003), 139-170.

3. Grant Evans, "Internal Colonialism in the Central Highlands of Vietnam," Sojourn 7, no. 2 (1992): 274-304; Oscar Salemink, "The King of Fire and Vietnamese Ethnic Policy in the Central Highlands," in Development or Domestication? Indigenous Peoples of Southeast Asia, eds. Don McCaskill and Ken Kampe (Chiang Mai: Silkworm Books, 1997), 488-535; Pamela McElwee, 
"Becoming Socialist or Becoming Kinh? Government Policies for Ethnic Minorities in the Socialist Republic of Vietnam," in Civilizing the Margins: Southeast Asian Government Policies for the Development of Minorities, ed. Christopher R. Duncan (Ithaca, NY: Cornell University Press, 2004), 182-213.

4. Condominas, L'Exotique est Quotidien.

5. Hickey, Shattered World, xvi.

6. Gerald Hickey's Free in the Forest contains a remarkable passage recording his initial impressions of highland life during his first trip to the highlands (Ban Mê Thuột) in June 1956: "For the first time ... I saw the rousseauean late afternoon scene in a highland village when the air is still and a thin veil of smoke from the evening cooking fires settles amidst the longhouses and luxuriant foliage all around. Villagers walk in silence, returning from the forest and fields with their backbaskets laden with wild fruits, vegetables, and edible flowers. Villagers also gather by the nearby stream to bathe, while downstream the elephants frolic in the water against the backdrop of rich green bamboo groves." Hickey, Free in the Forest: Ethnohistory of the Vietnamese Central Highlands 1954-1976 (New Haven, CT: Yale University Press, 1982), 20-21.

7. "Until recently upland communities, although not completely isolated and always engaged in some trade, were in many respects autonomous. Decisions about resource management were largely in the hands of villagers themselves. Knowledge was essentially 'local knowledge' and, as has been observed in other cultures, the local ('little') traditions were more important than any national ('great') tradition." Comment by Neil Jamieson, Lê Trọng Cúc, and Terry Rambo in their report, “The Development Crisis in Vietnam's Mountains," reprinted in Terry A. Rambo, Searching for Vietnam: Selected Writings on Vietnamese Culture and Society (Kyoto: Kyoto University Press, 2005), 351.

8. R.H. Barnes, Andrew Gray, and Benedict Kingsbury, eds., Indigenous Peoples of Asia (Ann Arbor, MI: Association for Asian Studies 1995); Don McCaskill and Ken Kampe, eds., Development or Domestication? Indigenous Peoples of Southeast Asia (Chiang Mai: Silkworm Books, 1997); Leslie Sponsel, ed., Endangered Peoples of Southeast and East Asia: Struggles to Survive and Thrive (Westport, CT: Greenwood Press, 2000).

9. "Trekking from Dalat to the Central Highlands," Pilot Guides website, www.pilotguides.com/destination_guide/asia/vietnam/trekking_vietnam_ central_highlands.php (accessed March 2008).

10. Condominas, L'Exotique est Quotidien.

11. Condominas' passionate indictment of the annihilation of an entire way of life has been influential beyond the walls of the academy. Half a century later, the Mnong Gar, still living in the highlands, are reportedly still poised on the brink of extinction. One trekking company lists their villages among the highlights 
of a trek to the Central Highlands, touting the adventure thus: "Best Sights: Endangered Hill Tribes and the Rare White Elephant." See “Trekking from Dalat to the Central Highlands," Pilot Guides website.

12. Hickey, Shattered World, xiv.

13. "Local knowledge is increasingly considered secondary, and often inferior, to national culture as processed and distributed by the mass media. Traditional ethnic dress, for example, is being replaced by modern lowland styles at a rapid and accelerating rate. This process of integration into a larger cultural system, although having potentially liberating aspects, decreases local control over information flow, weakens local symbols of identity, and converts upland people from producers to consumers of culture. Their lack of fluency in the national language and low level of literacy put them at gross disadvantage within the new, larger cultural system" (Jamieson, Lê Trọng Cúc, and Rambo, “The Development Crisis," in Rambo, Searching for Vietnam, 353).

14. Hickey, Free in the Forest, 16-46.

15. Jamieson, Lê Trọng Cúc, and Rambo, "The Development Crisis," in Rambo, Searching for Vietnam, 345-346, 356-362.

16. Charles Keyes, "Tribal Peoples and the Nation-State in Mainland Southeast Asia," in Cultural Survival, Inc., Southeast Asian Tribal Groups and Ethnic Minorities, A Cultural Survival Report (Cambridge, MA: Cultural Survival, Inc., 1987), 21.

17. Salemink, "The King of Fire and Vietnamese Ethnic Policy in the Central Highlands," 513 .

18. McElwee, "Becoming Socialist or Becoming Kinh?" 199.

19. James C. Scott, Seeing Like a State: How Certain Schemes to Improve the Human Condition Have Failed (New Haven, CT: Yale University Press, 1998).

20. Andrew Hardy's historical research examines the rationale for uplands resettlement schemes, the attitudes of state planners, and the experiences of migrants, but it provides little evidence about the effects of this massive population redistribution on ethnic minorities or about interactions between migrants and indigenous locals. Andrew Hardy, Red Hills: Migrants and the State in the Highlands of Vietnam (Singapore: ISEAS, 2003). Pamela McElwee's ethnographic research into migration to the hills of Hà Tĩnh concentrates solely on the expectations and experiences of the lowland migrants. McElwee, "There Is Nothing That Is Difficult: History and Hardship on and after the Ho Chi Minh Trail in North Vietnam," Asia-Pacific Journal of Anthropology 6, no. 3 (2005): 197-214.

21. Hickey describes his interviews with a number of state officials for evidence of his assimilation thesis (Free In the Forest, 30-34). Grant Evans provides some statistics on the migration of ethnic majority Việts to the Central Highlands 
and has a few references to the adverse effects on the environment, but his comments on the adverse effects this may be having on indigenous locals and about their reaction to this influx are merely speculative. See Evans, "Internal Colonialism in the Central Highlands of Vietnam"; "Central Highlanders of Vietnam," in Indigenous Peoples of Asia, eds. R.H. Barnes, Andrew Gray, and Benedict Kingsbury (Ann Arbor, MI: Association for Asian Studies, 1995), 247-272.

22. Rambo and Jamieson provide figures for resettlement of lowlanders into the hills but only speculate that the demonstrations by minorities over land rights in 2001 may have been linked in large part to this influx of migrants (Rambo and Jamieson, "Upland Areas, Ethnic Minorities and Development," 147). They refer to the phenomenon of upland minorities internalizing mainstream stereotypes about themselves as "ignorant," "superstitious," and "backward," but these authors do not make clear if this phenomenon is due to interactions between the indigenous uplanders and migrants or to the uplanders' exposure to such ideas in school, the mass media, or in their dealings with state officials $\left(155^{-156) .}\right.$

23. McElwee gives an account of the government's resettlement policies and provides some population figures but provides no evidence for her claims about the "great bitterness" and "hardship" experienced by ethnic minorities as a result of this program ("Becoming Socialist or Becoming Kinh?" 201).

24. Salemink has a brief but empirically rich account of the seriously destabilizing effects on the indigenous peoples of the Central Highlands of migration from the lowlands and related factors. This destabilization, which in part results from the loss of customary access to resources, is compounded by official restrictions on indigenous livelihood strategies and nonrecognition of traditional land rights. His evidence shows how indigenous people have been disadvantaged in relation to the lowlanders in the processes of decollectivization, marketization, the commoditization of land, and forest enclosures. See Oscar Salemink, "Enclosing the Highlands: Socialist, Capitalist and Protestant Conversions of Vietnam's Central Highlanders" (paper presented at "Politics of the Commons: Articulating Development and Strengthening Local Practices," Chiang Mai, Thailand, July 11-14, 2003: 11-18.)

25. Hickey provides some information on the negative perceptions of some highland minority leaders regarding lowland migrants (Free in the Forest, 36-44). Salemink also presents a few comments by indigenous highlanders who are critical of the preferential treatment that the authorities offer to Kinh settlers ("The King of Fire," 511).

26. Hickey, Free in the Forest.

27. Salemink, "Enclosing the Highlands." 
28. Thomas Sikor, "Agrarian Differentiation in Post-socialist Societies: Evidence from Three Upland Villages in North-Western Vietnam," Development and Change 32 (2001): 923-949.

29. Trần Thị Thu Trang, "From Collectivization to Globalization: Social Differentiation in a Muong Ethnic Community of Vietnam," in Social Inequality in Vietnam and the Challenges to Reform, ed. Philip Taylor (Singapore: ISEAS, 2004), 123-165; Trần Thị Thu Trang, "Local Politics and Democracy in a Muong Ethnic Community," in Beyond Hanoi: Local Government in Vietnam, eds. Benedict J. Tria Kerkvliet and David Marr (Singapore: ISEAS, 2004), 137-166.

30. Jennifer Sowerwine, "The Political Ecology of Dao (Yao) Landscape Transformations: Territory, Gender and Livelihood Politics in Highlands Vietnam" (PhD dissertation, University of California, Berkeley, 2004).

31. See Philip Taylor, "Poor Policies, Wealthy Peasants: Alternative Trajectories of Rural Development in Vietnam," Journal of Vietnamese Studies 2, no. 2 (2007): 3-56; Philip Taylor, "Economy in Motion: Cham Muslim Traders in the Mekong Delta," Asia-Pacific Journal of Anthropology 7, no. 3 (2006): 237-250. A historical perspective on Chinese translocal networks in the Mekong Delta is found in Nola Cooke and Tana Li, eds., Water Frontier: Commerce and the Chinese in the Lower Mekong Region, 1750-188o (Boulder, CO: Rowman and Littlefield, 2004).

32. This case is made most eloquently by Rie Nakamura in her comparative study of the Cham in Central Vietnam and the Mekong Delta: "Cham in Vietnam: Dynamics of Ethnicity” (PhD dissertation, University of Washington, 1999). The intercultural dynamics that shape Cham origin narratives, religious practices, and political identities are discussed in Philip Taylor, Cham Muslims of the Mekong Delta: Place and Mobility in the Cosmopolitan Periphery (Honolulu: University of Hawai'i Press; Singapore: National University of Singapore Press, 2007).

33. Philip Taylor, "Poor Policies, Wealthy Peasants," 43-46; Philip Taylor, "Redressing Disadvantage or Re-arranging Inequality? Development Interventions and Local Responses in the Mekong Delta," in Social Inequality in Vietnam and the Challenges to Reform, ed. Philip Taylor (Singapore: ISEAS, 2004), 236-269.

34. Benedict R. O'G Anderson, introduction to Southeast Asian Tribal Groups and Ethnic Minorities: Prospects for the Eighties and Beyond (Cambridge MA: Cultural Survival, Inc., 1987), 1-16.

35. Oscar Salemink, The Ethnography of Vietnam's Central Highlanders: A Historical Contextualization, 1850-1990 (London: RoutledgeCurzon, 2003).

36. Nakamura, "Cham in Vietnam: Dynamics of Ethnicity," 148-157; Philip Taylor, Cham Muslims of the Mekong Delta. 
37. Dominique Van De Walle and Dileni Gunewardene, "Sources of Ethnic Inequality in Vietnam," Journal of Development Economics 65 (2001):177-207; Bob Baulch et al., Ethnic Minority Development in Vietnam: A Socio-economic Perspective, Working Paper 2836 (Washington, DC: World Bank, 2002); Huỳnh Thử Ba, Dủonng Bích Hạnh, and Bùi Thế Cường, Indigenous Peoples/Ethnic Minorities and Poverty Reduction: Viet Nam (Manila, Philippines: Asian Development Bank, 2002); Sandra Huang, Ethnic Minority Development in Vietnam: Situation Analysis, A Report for Oxfam, Great Britain, Oxfam, Hong Kong, and Oxfam, Quebec (Hà Nội: Oxfam, 2005).

38. For a discussion of these perspectives, see Philip Taylor, "Social Inequality in a Socialist State," in Social Inequality in Vietnam and the Challenges to Reform, ed. Philip Taylor (Singapore: ISEAS, 2004), 1-40; Philip Taylor, "Redressing Disadvantage or Re-arranging Inequality?," 236-269.

39. Philip Taylor, "Poor Policies, Wealthy Peasants."

40. For instance, see Alexander Woodside's classic study, Vietnam and the Chinese Model (Cambridge, MA: Harvard University Press, 1971).

41. An alternative model of "decentered transnationalism" is presented in Philip Taylor, "Poor Policies, Wealthy Peasants," $38-41$.

42. WriteNet, Vietnam: Indigenous Minority Groups in the Central Highlands, WriteNet Paper No. 05/2001 (UNHCR Centre for Documentation and Research, 2001).

43. Based on my field observations among Khmer Krom communities in southern Vietnam from 1999 to the present.

44. Salemink, "Enclosing the Highlands"; Philip Taylor, "Redressing Disadvantage or Re-arranging Inequality?" 236-269; Philip Taylor, Cham Muslims of the Mekong Delta; Philip Taylor, "Poor Policies, Wealthy Peasants," 43-46.

45. Speech by Lê Công Phụng, First Deputy Minister for Foreign Affairs of Viet Nam to the Fifty-ninth UN General Assembly Plenary, 11th and 12th Meetings, UN General Assembly Press Release GA/10263 (New York: United Nations General Assembly, September 27, 2004).

46. I am aware from private discussions with Vietnamese government officials and intellectuals that Khmer Krom case is considered a "sensitive," "dangerous," and "complicated" issue. The list of nefarious outsiders who are alleged to be behind the recent rise in assertiveness by the Khmer in Vietnam includes the Khmer Krom diaspora (mostly living in Cambodia, America, Australia, Canada, and France), ethnonationalist politicians in Cambodia, foreign anthropologists working with the Khmer, such as myself, and, most intriguingly, the Chinese government. The case made by the ethnic Khmer is the opposite: marginalized by state policies, subject to assimilation and disparagement of their culture, they are driven to seek allies overseas, flee to Cambodia, 
and imagine an alternative to living under national Vietnamese rule. See, for instance, the documentary film about the Khmer Krom, Eliminated without Bleeding, produced by Rebecca Sommer (New York: Sommer Films, 2006).

47. Sarah Davis, Song and Silence: Ethnic Revival on China's Southeast Borders (New York: Columbia University Press, 2005); Philip Taylor, Cham Muslims of the Mekong Delta. James Anderson's study of the eleventh-century Tai rebel Nùng Trí Cao in the Sino-Vietnamese borderlands shows that the agency exercised by peoples moving in the interstices between larger political formations in Southeast Asia has an ancient pedigree, and it continues to be the stuff of legends that unite groups divided by contemporary political borders. James Anderson, The Rebel Den of Nùng Trí Cao: Loyalty and Identity Along the Sino-Vietnamese Frontier (Seattle: University of Washington Press, 2007).

48. Baulch et al., Ethnic Minority Development in Vietnam, 4, 6-9, 18; Huang, Ethnic Minority Development in Vietnam, 16, 34, 41.

49. James Lewis, "The Evangelical Religious Movement among the Hmong in Vietnam and the Government's Response: 1989-2000," Crossroads: An Interdisciplinary Journal of Southeast Asian Studies 16, no. 2 (2002): 79-112; Vủong Duy Quang, "Hiện Tượng 'Xủng Vua' ở Cộng Đồng Hmông” [The Phenomenon of 'Proclaiming a King' in the Hmong Community], in Ngưòi Hmông [Hmong People], ed. Chu Thái Sỏn (HCMC: Trẻ, 2005), 121-135.

50. Based on my field observations in southern Vietnam. See also Philip Taylor, Goddess on the Rise: Pilgrimage and Popular Religion in Vietnam (Honolulu: University of Hawai'i Press, 2004), 68-74.

51. René Dubrueil, De la condition des Chinois et de leur rôle economique en Indochine [On the Condition of the Chinese and Their Economic Role in Indochina] (Bar-sur-Seine: Imprimerie Saillard, 1910), 71; Martin Murray, The Development of Capitalism in Colonial Indochina (1870-1940) (Berkeley and Los Angeles: University of California Press, 1980), 449-457.

52. Lucien Bodard, The Quicksand War: Prelude to Vietnam (Boston: Little, Brown, and Co., 1967).

53. Anthony Reid, "Entrepreneurial Minorities, Nationalism and the State," in Essential Outsiders: Chinese and Jews in the Modern Transformation of Southeast Asia and Central Europe, eds. Daniel Chirot and Anthony Reid (Seattle: University of Washington Press, 1997), 33-71.

54. Nguyễn Khắc Viện, Vietnam '78 (Hà Nội: Foreign Languages Publishing House, 1978).

55. Nguyễn Khắc Viện, “A Mosaic of Nationalities," Vietnamese Studies 15 (1968):11; Đặng Nghiêm Vạn, "Ethnic Classification in Vietnam: Principles and Processes," in Ethnological and Religious Problems in Vietnam, ed. Đặng Nghiêm Vạn (Hà Nội: Khoa Học Xã Hội, 2001), 9-59. 
56. For instance, "local" scholars Huỳnh Thủ Ba, Dủong Bích Hạnh, and Bùi Thế Cuiòng have expressed reservations about the evolutionary premises of official development policies that assume the majority ethnic group should be the model for other groups to follow (Indigenous Peoples/Ethnic Minorities and Poverty Reduction: Viet Nam, 19). The "foreign" scholar Oscar Salemink offers a penetrating critique of the ethnic policies that were an integral part of colonialist ventures (The Ethnography of Vietnam's Central Highlanders).

57. For one anthropologist's description of the difficulties researching in the Central Highlands in the 1960s and 1970s, see Hickey, Shattered World, xvi.

58. Grant Evans, "Vietnamese Communist Anthropology," Canberra Anthropology (Special Volume on Minorities and the State) 8, nos. 1\&2 (1985): 116-147; "Internal Colonialism in the Central Highlands of Vietnam"; "Central Highlanders of Vietnam."

59. Salemink, The Ethnography of Vietnam's Central Highlanders; Jean Michaud, 'Incidental' Ethnographers: French Catholic Missions on the Tonkin-Yunnan Frontier, 1880-1930 (Leiden: Brill, 2007).

6o. Patricia Pelley, Postcolonial Vietnam: New Histories of the National Past (Durham, NC: Duke University Press, 2002), 69-112.

61. Keith Taylor, "On Being Muonged," Asian Ethnicity 2, no. 1 (2001): 25-34.

62. Susan Bayly, "French Anthropology and the Durkheimians in Colonial Indochina," Modern Asian Studies 34 (2000): 581-627.

63. Charles Keyes, "The Peoples of Asia: Science and Politics in Ethnic Classifications in Thailand, China and Vietnam," Journal of Asian Studies 61, no. 4 (2002): 1163-1203.

64. Priscilla Koh, "Persistent Ambiguities: Vietnamese Ethnology in the Doi Moi Period (1986-2001)," Explorations in Southeast Asian Studies 5, no. 1 (Spring 2004): 1-19.

65. Nguyễn Văn Huy, "Nhìn Lại 15 Năm Nghiên Cû̉u Sự Phát Triển Các Quan Hệ Dân Tộc ở Nước Ta” [Looking Back on Fifteen Years of Research on the Development of Ethnic Relations in Our Country], Dân Tộc Học 4 (1983); Đặng Nghiêm Vạn, "Ethnic Classification in Vietnam: Principles and Processes”; Presentations by Nguyễn Ngọc Phương, Trương Huyền Chi, Nguyễn Văn Chính, and Nguyễn Văn Huy in the panel "Twentieth-Century Vietnamese Anthropology Contextualized: Debates and Contestations," Association for Asian Studies Annual Meeting, March 22-25, 2007, Boston.

66. See Evans, "Vietnamese Communist Anthropology"; Pelley, Postcolonial Vietnam; Salemink, The Ethnography of Vietnam's Central Highlanders; Keyes, "The Peoples of Asia"; McElwee, "Becoming Socialist or Becoming Kinh?”; Koh, "Persistent Ambiguities." 
67. The situation regarding the utilization of vernacular languages for field research among minority ethnic groups is less promising; many fieldworkers still rely principally on the national language, quốc ngứ, as the language of field research.

68. Nguyễn Văn Thắng, Ambiguity of Identity: The Mieu in North Vietnam (Chiang Mai: Silkworm Books, 2007).

69. Rie Nakamura, "Cham in Vietnam: Dynamics of Ethnicity."

70. Masako Ito, The Creation of Ethnicity and the Nation-State Vietnam: The Tay and Nung Ethnic Minorities around the Sino-Vietnamese Border Region in Contemporary History [in Japanese] (Tokyo: Sangensha, 2003).

71. See Kashinaga Masao on the Tai Dam chronicle "Quam To Muang": TounanAjia Nendaiki no Sekai: Kuro-Tai no 'Quam To Muang' [The World of the Chronicles in Southeast Asia: 'Quam To Muang' of the Tai Dam] (Tokyo: Fukyosha, 2007). Also see Nakanishi Yuji, "Some Aspects of Ong Bon in Southern Vietnam" (paper presented at the conference "Modernities and Dynamics of Tradition in Vietnam: Anthropological Approaches," Bình Châu, Vietnam, December 15-18, 2007).

72. LiAnne Yu, “The Re-emergence of Vietnam's Ethnic Chinese Community through Local, National and Transnational Structures" (PhD dissertation, University of California, San Diego, 2006).

73. Dủong Bích Hạnh, "The Hmong Girls of Sa Pa: Local Places, Global Trajectories, Hybrid Identities" (PhD dissertation, University of Washington, 2006). Also, Dủỏng Bích Hạnh, Through Hmong Eyes (Hà Nội: Vietnam National Museum of Ethnology, 2003).

74. Thien Do, Vietnamese Supernaturalism: Views from the Southern Region (London: RoutledgeCurzon, 2003).

75. For a discussion of the conceptions of ethnic difference that arise amid the intense intercultural traffic in goddess shrines in the Mekong Delta, see Philip Taylor, "The Ethnicity of Efficacy: Vietnamese Goddess Worship and the Encoding of Popular Histories," Asian Ethnicity 3, no. 1 (2002): 85-102.

76. Philip Taylor, Cham Muslims of the Mekong Delta, 112-120. 